Gut, 1975, 16, 421-428

\title{
Hepatitis-associated-antigen-positive hepatitis in a tuberculosis unit
}

\author{
G. R. FITZGERALD, H. GRIMES, M. REYNOLDS, H. HITCHCOCK, AND \\ C. F. McCARTHY ${ }^{1}$
}

From the Departments of Gastroenterology and Medical Biochemistry, Regional Hospital, Merlin Park Hospital, and University College, Galway

SUMMARY An outbreak of hepatitis-associated-antigen-(HB Ag)-positive hepatitis in a hospital unit for the care of male patients with pulmonary tuberculosis is described. Sixty-four patients were studied of whom 37 were HB Ag positive. Hepatitis developed in at least 20 and was icteric in 11 . The illness was mild, without fatality due to hepatitis and persistent jaundice did not occur. A carrier state developed in 15 of $24 \mathrm{HB}$ Ag-positive patients followed up for more than six months and was unrelated to the presence or absence of initial hepatitis. Spread of HB Ag to domestic and medical staff occurred and following the discharge of the patients, household contacts became positive. Five, all wives of patients, developed jaundice. Faeces and sputum were HB Ag negative in seropositive cases. The origin of the outbreak remains undetected. The probability of non-parenteral transmission of HB Ag in this outbreak is discussed. Closure of the unit, isolation of HB Ag-positive cases with separate toilet and kitchen facilities, and discharge of patients when their respiratory condition allowed, resulted in prevention of further spread and eventually all patients were discharged from the unit.

Virus hepatitis is separated into two types on the basis of associated antigens and incubation period. Virus A hepatitis (acute infective, epidemic, IH MS-1) occurs in pinpoint epidemics, has a short incubation period (Krugman, Giles, and Hammond, 1967; Berg, Vellar, and Nesvoid, 1971; Ajdukiewicz, Fox, Dudley, Doniach, and Sherlock, 1972), and may be associated with Milan antigen HB Ag (Del Prete, Constantino, Doglia, Graziina, Ajdukiewicz, Dudley, Fox, and Sherlock, 1970; Ajdukiewicz et al, 1972). Virus B hepatitis (serum, SH, MS-2) follows parenteral infection, but also occurs in sporadic cases in adults, particularly in urban areas (Cossart and Varhman, 1970; Prince, Hargrove, Szmuness, Cherubin, Fontane, and Jeffries, 1970). The incubation period is longer (Krugman et al, 1967) and Australia antigen ( $\mathrm{HB} \mathrm{Ag}$ ) is detected in the preicteric and early icteric phases. Anicteric forms of both types occur (Krugman et al, 1967).

Virus B hepatitis may be acquired by ingestion of serum (Krugman et al, 1967; Prince et al, 1970).

${ }^{1}$ Please send requests for reprints to Professor C. F. McCarthy, Regional Hospital, Galway

Received for publication 12 March 1975.
Other suggested non-parenteral modes of transmission include airborne spread with inhalation or ingestion of $\mathrm{HB} \mathrm{Ag}$ (Almeida, Kulatilake, Mackay, Shackman, Chisholm, MacGregor, O'Donoghue, and Waterson, 1971) and venereal spread (Hersh, Melnick, Goyal, and Hollinger, 1971; Jeffries, James, Jefferiss, MacLeod, and Willcox, 1973). Prince (1971) reported that all patients in an institution for the mentally retarded became infected with $\mathrm{HB} \mathrm{Ag}$ within one year of entering the hospital. He also found $\mathrm{HB} \mathrm{Ag}$ in $10 \%$ of families of $\mathrm{HB} \mathrm{Ag}$ carriers. Family spread and spread to close contacts of virus B subjects has been described by Mirick and Shank (1959), Blumberg, Melartin, Guinto, and Werner (1966), and Wright, Perkins, Bower, and Jerrome (1970). HB Ag has also been found in the saliva and semen of HB Ag-positive patients (Heathcoate, Cameron, and Dane, 1974).

Smooth muscle antibodies, although usually associated with chronic liver disease, have been noted in virus A and virus B hepatitis (Walker, Doniach, Willette, Cameron, and Dane, 1970; Ajdukiewicz et al, 1972). Antinuclear and antimitochondrial antibodies were not found in their patients.

The discovery of $\mathrm{HB} \mathrm{Ag}$-positive hepatitis in an 


\begin{tabular}{|c|c|c|c|c|c|c|c|c|c|c|c|c|}
\hline \multirow{3}{*}{$\begin{array}{l}\text { Patient } \\
\text { No.(Age yr) }\end{array}$} & \multirow{3}{*}{$\begin{array}{l}\text { Date of Admission to } \\
\text { Unit }\end{array}$} & \multicolumn{9}{|c|}{ HB Ag Tests } & \multirow[t]{3}{*}{ Latest HB Ag Test } & \multirow[t]{3}{*}{ Stait of Injections } \\
\hline & & \multicolumn{5}{|l|}{1971} & \multicolumn{4}{|l|}{1972} & & \\
\hline & & Aug. & Sept. & oct. & Nov. & Dec. & Jan. & $F e b$. & Mar. & Apr. & & \\
\hline $01(79)$ & 28.8.61 & & & - & - & & & & - & - & $\begin{array}{l}-21.5 .73 \\
\text { Died July } 1973\end{array}$ & None \\
\hline $02(42)$ & $\begin{array}{l}2.6 .70 \\
(1966,67,69)\end{array}$ & + & + & & & & & & & & +20.9 .71 & S 1966, 1967, 1969 \\
\hline $03(61)$ & $\begin{array}{l}2.9 .70 \\
\text { (Unknown) }\end{array}$ & + & + & & & & & & & & +17.8 .73 & Unknown \\
\hline $04(69)$ & 9.3.71 & + & + & + & - & - & + & - & & & -6.12 .72 & S 12.3.71 \\
\hline $\begin{array}{l}05(60) \\
06(66)\end{array}$ & $\begin{array}{r}12.3 .71 \\
7.5 .71\end{array}$ & & + & $\begin{array}{l}+ \\
+\mathrm{H}\end{array}$ & $\begin{array}{l}+ \\
+\end{array}$ & - & - & & + & & +8.11 .71 & S 12.3 .71 \\
\hline $07(70)$ & 12.5 .71 & & + & + & & + & & & + & & +3.3 .72 & S 8.5.71 \\
\hline & (1969) & & & & & & & & & & $\begin{array}{l}\text { Died } \\
\text { Dec. } 1971\end{array}$ & $\begin{array}{l}\text { S 10.2.69 } \\
\text { I 4.11.69 }\end{array}$ \\
\hline $08(57)$ & 17.5 .71 & & & + & + & & & & & & +20.10 .73 & S 18.5.71 \\
\hline $09(16)$ & 19.5.71 & & + & + & - & - & & & & & -17.12 .71 & S 20.5.71 \\
\hline $10(73)$ & 21.5 .71 & & + & + & - & - & - & & & & -17.8 .73 & S 21.5.71 \\
\hline 11 & 24.5.71 & & $-*$ & + & & & & + & & & +9.3 .72 & S 24.5.71 \\
\hline $12(75)$ & 27.5.71 & & + & + & & & & & & & +2.10 .73 & S 27.5.71 \\
\hline $13(55)$ & 11.6 .71 & & & + & & + & & & & & +20.10 .73 & S 2.6.71 \\
\hline $14(32)$ & 8.6 .71 & & & + & + & + & - & - & - & & -21.5 .72 & None \\
\hline $15(50)$ & 12.6 .71 & * & & $-\mathbf{H}$ & & + & + & & + & & +5.6 .73 & None \\
\hline $16(65)$ & 14.6 .71 & & $+\mathbf{H}$ & + & + & - & + & - & + & + & -7.8 .73 & 14.6.71 \\
\hline $17(54)$ & 21.6.71 & $+\mathbf{H}$ & + & - & - & - & & & & & -17.8 .73 & \\
\hline $18(48)$ & 24.6.71 & - & - & * & & & & & & & -17.8 .73 & None \\
\hline $19(51)$ & 26.6.71 & - & * & & & & & & & & -4.9 .71 & None \\
\hline $20(58)$ & 30.6.71 & & + & $*$ & & & & & - & & -17.8 .73 & S 30.6.71 \\
\hline $21(63)$ & 8.7 .71 & & + & & & & & & & & $\begin{array}{l}\text { Died } \\
\text { Nov } 1971\end{array}$ & S 30.6.71 \\
\hline $22(27)$ & 12.7.71 & & - & $*$ & & - & & & & & -3.7 .73 & S 12.7.71 \\
\hline $23(27)$ & 19.7.71 & & - & - & $*+\mathbf{H}$ & & & & & & +15.11 .72 & S 19.7.71 \\
\hline $24(26)$ & 3.8.71 & & - & * & & & & & & & -9.10 .71 & S 5.8.71 \\
\hline $25(30)$ & 23.8.71 & & - & - & * & & & & & + & +5.4 .72 & S 24.8.71 \\
\hline $26(58)$ & 27.8.71 & & - & $-*$ & + & $\mathbf{H}$ & & & - & & -17.8 .73 & S 28.8.71 \\
\hline $27(60)$ & 27.8.71 & - & + & - & - & - & - & & & - & $\begin{array}{l}\text { Died } \\
\text { Jan } 1973\end{array}$ & S 28.8.71 \\
\hline $28(52)$ & 30.8.71 & & - & - & - & - & & - & - & & -10.7 .72 & None \\
\hline $29(82)$ & 30.8 .71 & & - & - & + & + & + & & & & $\begin{array}{l}+ \text { Died } \\
\text { Feb } 1972\end{array}$ & $\begin{array}{l}\text { S 30.8.71 } \\
\text { Blood } \\
2.9 .71\end{array}$ \\
\hline $30(68)$ & $\begin{array}{r}30.8 .71 \\
6.71\end{array}$ & & $-*$ & - & + & & & & & & $\begin{array}{l}-18.5 .72 \\
+19.1073\end{array}$ & $\begin{array}{l}\text { S } 1.9 .71 \\
S 1970\end{array}$ \\
\hline $31(56)$ & $\begin{array}{r}6.9 .71 \\
13.9 .71\end{array}$ & $\pm^{*}$ & _- & - & + & $+\mathbf{H}$ & & & & & +19.10 .73 & S 1970 \\
\hline $32(70)$ & 13.9.71 & & & & & $T_{\mathbf{M}}$ & & + & + & & $\begin{array}{l}\text { +Died } \\
\text { Jan } 1973\end{array}$ & S 13.9.71 \\
\hline $\begin{array}{l}33(64) \\
34(66)\end{array}$ & $\begin{array}{l}22.9 .71 \\
1.10 .71\end{array}$ & - & - & - & $\begin{array}{l}+ \\
+\end{array}$ & $\bar{t}$ & $\begin{array}{l}-\mathbf{H} \\
+\mathbf{H}\end{array}$ & $\bar{t}$ & + & $\begin{array}{l}+ \\
+\end{array}$ & $\begin{array}{l}\text { - } 9.10 .73 \\
\text { +Died }\end{array}$ & $\begin{array}{l}\text { S } \\
\text { S } 1.10 .71\end{array}$ \\
\hline & & & & & & & & & & & June 1973 & \\
\hline
\end{tabular}

Table I Details of patients admitted to the unit, dates of admissions, the dates on which HB Ag tests were done and on which hepatitis occurred are indicated together with the initial injections received by the patients

isolated unit for the therapy of tuberculosis provided an opportunity to examine the incidence of $\mathrm{HB} \mathbf{A g}$ hepatitis and anicteric hepatitis, the mode of transmission, the incubation period, the persistence of $\mathrm{HB} \mathrm{Ag}$, family spread of $\mathrm{HB} \mathrm{Ag}$, and the occurrence of autoantibodies in the infected patients.

\section{Materials and Methods}

Eight HB Ag-positive cases were detected from a total of 272 patients' sera submitted to the laboratory of the Regional Hospital, Galway, for routine biochemical investigations in August 1971. Six of the eight were patients in a 50-bed tuberculosis unit in another hospital, while the remaining two (code nos. 02,03 , table I) were expatients of that unit. Occasional cases of jaundice had been noted in the unit in the previous two years, and at the time of discovery of HB Ag-positive sera, three patients (codes $04,10,17$, table I) were jaundiced, while the two expatients (codes 02, 03) were jaundiced in another hospital. From 1 September 1971 all patients (aged 16-82 years; mean age 58) and staff of the unit had HB Ag, serum aspartate aminotransferase (SGOT) and serum bilirubin levels monitored at two-weekly intervals, where possible. All routine blood specimens sent to the laboratory from all other units in the hospital, including the female tuberculosis unit 


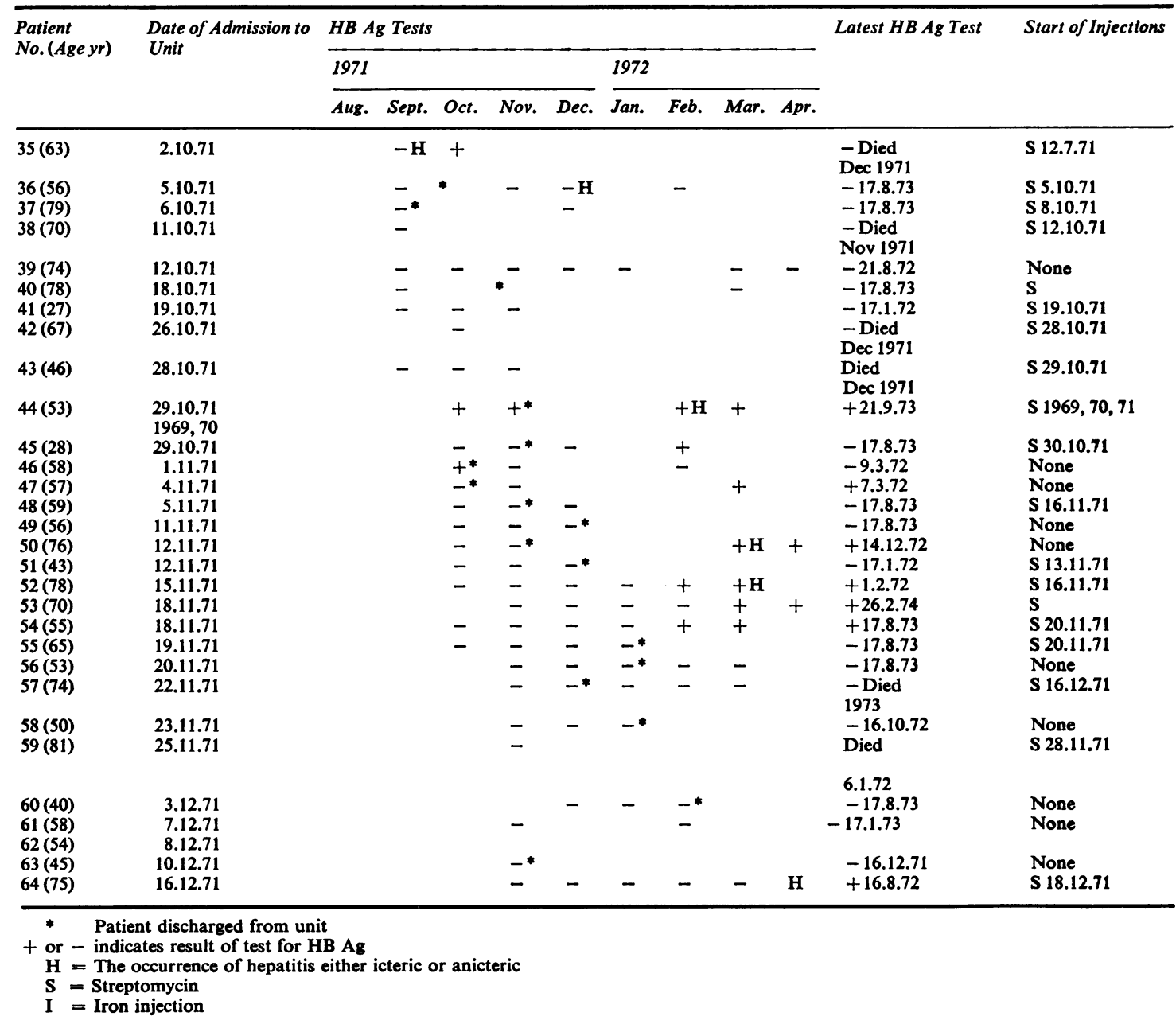

Table 1 Details of patients admitted to the unit, dates of admissions, the dates on which HB Ag tests were done and on which hepatitis occurred are indicated together with the initial injections received by the patients-continued

were screened for $\mathrm{HB}$ Ag during the period studied. Household contacts of discharged patients had HB Ag, SGOT, and bilirubin checked once after the patient's discharge from the unit in March and April 1972. Because of the large area of western Ireland in which the patients resided and the remoteness of their dwellings it was only possible to follow small numbers of the patients outside hospital. Domiciliary samples were collected by the authors, the family doctor, and the public health authorities of the appropriate areas. Liver biopsy was performed on one patient (no. 27) because his abnormal liver enzyme pattern was not suggestive of acute hepatitis.

Fifteen HB Ag-positive patients (code nos. 4, 6, 10,
$15,16,17,26,27,32,33,34,35,39,48,57)$ had antinuclear, smooth muscle, and antimitochondrial antibody tests done at the time of $\mathrm{HB} \mathrm{Ag}$ positivity. Faeces from $13 \mathrm{HB}$ Ag-positive patients and sputum from $10 \mathrm{HB}$ Ag-positive patients were examined for HB Ag.

The tuberculosis unit accepts male patients from the West of Ireland who have pulmonary tuberculosis proven or suspected. It is divided into four eightbed wards, one seven-bed ward, one six-bed ward, and five single rooms. There is a corridor, sittingroom, and canteen shared by the ambulant patients. Toilet facilities are also shared by ambulant patients. Cutlery and tableware are interchangeable among patients after being washed in the unit's kitchen. 
Laundry from the tuberculosis unit and from the other eight units of the hospital are dealt with by a central laundry in the grounds of the hospital. Shaving equipment and other personal toiletries were not shared at any time. All the patients have their own towels, and no others are provided. The water supply is that common to other units in the hospital.

The unit is staffed by doctors and nurses, a minority of whom have duties in other parts of the hospital. The domestic staff does not rotate to other units. There is a central $x$-ray department common to all units and this is visited by the ambulant patients when necessary. Disabled patients are radiographed with portable equipment. Blood specimens are sent to the Regional Hospital Laboratory. The patients receive visitors freely. The female tuberculosis unit is situated a quarter of a mile away in a separate building.

Techniques for phlebotomy and injections are similar. Disposable syringes and needles are used at all times and the patients do not have access to the used materials. Where streptomycin is used it is taken from a multiple-dose vial. All other parenteral drugs used are from single-dose ampoules. Most of the drugs used in the unit, eg, isoniazid, PAS, are given orally. All patients admitted have blood drawn for investigations within 24 hours of arrival at the unit. Erythrocyte sedimentation rates were not done in the unit after the outbreak was noticed. Parenteral drugs and the route of administration as well as the commencing date of therapy are noted in table I.

Criteria for diagnosis of hepatitis were those of Krugman et al (1967).

Serum from patients was frozen until tested, or was immediately screened for $\mathrm{HB} \mathrm{Ag}$ by immunoelectro-osmophoresis. Samples were heated at $55^{\circ} \mathrm{C}$ for 15 minutes before testing. A Hepascreen HB Ag detection kit marketed by Becton Dickinson was used with agar plates containing precut wells $3 \mathrm{~mm}$ in diameter with $5 \mathrm{~mm}$ centre-to-centre spacing. Antibody (human, $20 \mu 1$ ) was placed in the anodal wells and $20 \mu \mathrm{l}$ of $\mathrm{HB} \mathrm{Ag}$ or test serum in the cathodal wells. Oxoid barbitone acetate buffer, $\mathrm{pH} 8 \cdot 6$, ionic strength $0 \cdot 1$, was placed in the electrophoretic chamber and a voltage of 200 volts was applied for two hours. Visible precipitin lines between the anodal and cathodal wells were indicative of the presence of $\mathrm{HB} \mathrm{Ag}$.

Faecal HB Ag was examined by the technique of Grob and Jemelka (1971). Faeces (lg) was thoroughly mixed with $3 \mathrm{ml}$ of balanced Hart's solution containing $1 \mathrm{~g}$ of streptomycin, $1 \mathrm{~g}$ of chloramphenicol, and 2 million units of penicillin per $100 \mathrm{ml}$. The mixture was centrifuged at $3000 \mathrm{rpm}$ for 15 minutes and the supernatant tested for HB Ag. Sputum was tested directly unless it was too viscous, in which case it was thoroughly shaken with an equal volume of $0.9 \%$ saline, and the resulting solution tested. Total bilirubin, alkaline phosphatase, and aspartate aminotransferase were assayed in serum using the Technicon SMA 12/30 AutoAnalyzer.

Antinuclear, smooth muscle, and mitochondrial antibodies were detected by an immunofluorescent technique. Unfixed, $4 \mu$-thick cryostat sections of rat liver (for antinuclear antibodies), of mouse kidney (for mitochondrial antibodies), and of mouse stomach (for smooth muscle antibodies) were used. Sections were covered with the patient's serum for 30 minutes at room temperature, washed twice in phosphate-buffered saline (Difco Bacto FA buffer, pH 7.2) for 10 minutes. Specimens for antinuclear antibodies were partially dried and fixed for five minutes in ethanol and partially dried again. Sections were then covered with fluorescein-conjugated antihuman immunoglobulin serum (AHG horse origin fluorescein conjugate obtained from Roboz Surgical Instrument Co, Inc, Washington DC 2000E) for 30 minutes, washed in buffered saline as before, partially dried and mounted in buffered glycerol (Difco Bacto FA mounting fluid). Samples were examined microscopically using a Leitz microscope with ultraviolet source.

\section{Results}

Sixty-two patients who were in the unit in September 1971 or were subsequently admitted (until closure of the unit to new admissions in December 1971) were assessed, as well as two recent expatients of the unit who presented at another hospital with jaundice (codes 02, 03, table I). By April 1972, 37 were HB Ag positive (codes in table I, 02 to 17 inclusive, 20, 21, 23, 25, 26, 27, 29 to 35 inclusive 44 to $47,50,52,53$, 54 , and 64). Five of these (nos. 11, 15, 23, 25, 26) became $\mathrm{HB} \mathrm{Ag}$ positive shortly after discharge from the unit. The outcome in all the patients is shown in table II. Two patients (nos. 36 and 61), who became jaundiced, were (HB Ag) negative when tested.

HB AG IN OTHER HOSPITAL UNITS

$\mathrm{HB} \mathrm{Ag}$ was not detected in any other unit of the hospital. No cases of hepatitis were seen in the other units.

SPREAD OF HB AG TO STAFF

Four doctors, 13 nurses, five domestics, and one attendant were examined. One doctor and one nurse got hepatitis. Both had accidentally pricked themselves with needles used to take blood from $\mathrm{HB}$ Agpositive patients. A barber who visited the unit 


\begin{tabular}{|c|c|c|c|c|c|c|c|}
\hline \multirow[t]{2}{*}{$\begin{array}{l}\text { Patient } \\
\text { Code }\end{array}$} & \multirow[t]{2}{*}{$\begin{array}{l}\text { No. of } \\
\text { Patients }\end{array}$} & \multirow[t]{2}{*}{$\begin{array}{l}\text { Early Outcome } \\
(0-6 \mathrm{mth})\end{array}$} & \multicolumn{5}{|c|}{$\begin{array}{l}\text { Late Outcome } \\
(6-24 \mathrm{mth})\end{array}$} \\
\hline & & & $\begin{array}{l}\text { Persistent } \\
\text { Jaundice }\end{array}$ & $\begin{array}{l}\text { Persistent Carriers } \\
\text { Clinically Normal }\end{array}$ & $\begin{array}{l}\text { HB Ag-negative } \\
\text { Clinically Normal }\end{array}$ & Died during Study & Unknown \\
\hline $\begin{array}{l}02,03,04 \\
05,10,15 \\
17,23,26 \\
44,50\end{array}$ & 11 & Jaundice & 0 & 5 & 4 & $\mathbf{0}$ & 2 \\
\hline $\begin{array}{l}06,09,16 \\
31,33,34 \\
35,52,64\end{array}$ & 9 & $\begin{array}{l}\text { Anicteric } \\
\text { hepatitis }\end{array}$ & 0 & 5 & 0 & 1 & 3 \\
\hline $\begin{array}{l}01,07,08, \\
11,12,20 \\
27,29,31 \\
45,53,54\end{array}$ & 12 & $\begin{array}{l}\text { No jaundice } \\
\text { (possible anicteric } \\
\text { hepatitis) }\end{array}$ & & 5 & 3 & 3 & 1 \\
\hline $\begin{array}{l}13,14,21 \\
25,46,47\end{array}$ & 6 & $\begin{array}{l}\text { Lost to } \\
\text { follow-up }\end{array}$ & 0 & 0 & 0 & 1 & 5 \\
\hline \multicolumn{2}{|c|}{ Total 38} & & 0 & 15 & 7 & 5 & 11 \\
\hline
\end{tabular}

Table II Early and late outcome in $38 \mathrm{HB}$ Ag-positive cases

weekly was persistently negative. One laboratory technician who frequently handled blood from the unit presented at another hospital with HB Agpositive hepatitis. One other nurse and one domestic were transiently $\mathrm{HB} \mathrm{Ag}$ positive without evidence of hepatitis.

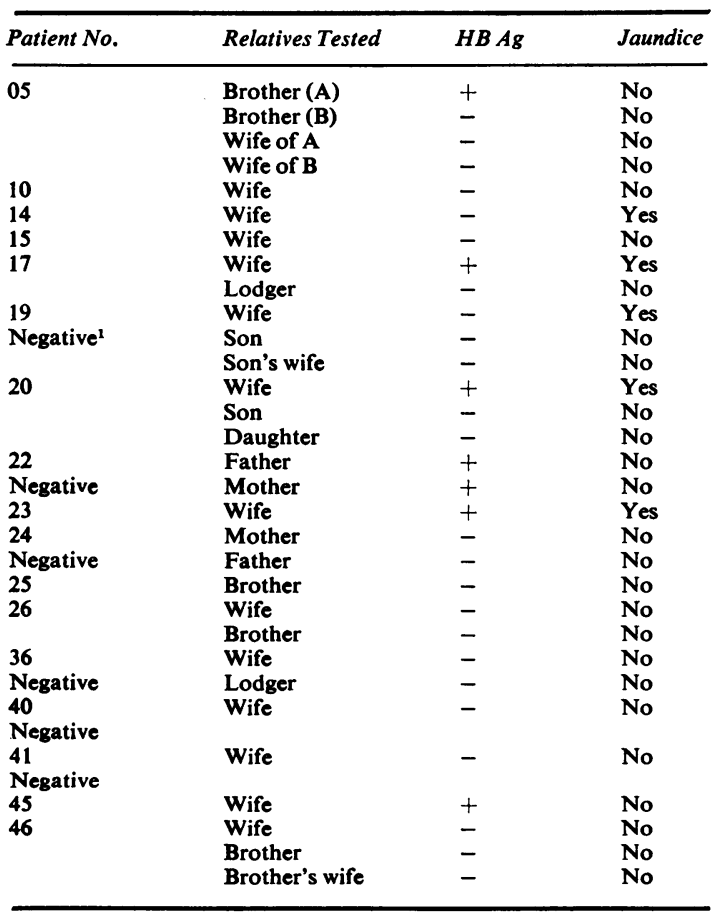

Table III Spread of HB Ag to relatives of patients

${ }^{1}$ Negative indicates patients who were $\mathrm{HB}$ Ag negative on all occasions on which the test was done.
SPREAD OF HB AG TO FAMILIES AND

CLOSE CONTACTS OF PATIENTS

Thirty-one close contacts of 17 patients were examined for $\mathrm{HB} \mathrm{Ag}$, jaundice, and biochemical liver abnormalities in March and April 1972. Six of the 17 patients were $\mathrm{HB} \mathrm{Ag}$ negative while they were in hospital (table III). Seven of the 31 contacts were HB Ag positive. Three of these were jaundiced. Two other relatives presented to another hospital with jaundice, but blood was not available at the optimum time for $\mathrm{HB} \mathrm{Ag}$ testing. Relationships are shown in table III. It is noticeable that all relatives who became jaundiced are wives of patients. Spread to relatives could not be correlated with the presence or absence of the $\mathrm{HB} \mathrm{Ag}$ carrier state in the contact patient (see tables III and IV). Wives became jaundiced on average 16 weeks after their husbands' discharge from the unit. It is interesting that the father and mother of one $\mathrm{HB}$ Ag-negative patient (case 22) were found to be $\mathrm{HB} \mathrm{Ag}$ positive. Insensitivity of the method used for detecting $\mathrm{HB} \mathrm{Ag}$ or inappropriate timing of the tests on this patient who was tested on two occasions only may account for this unexpected finding.

\section{INCUBATION PERIODS}

It was possible to measure the incubation period (time from admission to the units to onset of hepatitis) in 16 patients (code numbers $04,05,10,15$, $16,17,23,26,32,33,34,36,44,50,61,64)$. This varied from 14 to 34 weeks, being 14 to 21 weeks in 14 of these. Measurement of the interval between admission to the unit and development of $\mathrm{HB} \mathbf{A g}$ positivity revealed a wide range, four to 26 weeks (14 patients-code numbers $11,15,23,26,27,29,30,32$, $33,34,35,52,53$ and 64 ), and $\mathrm{HB}$ Ag positivity was 
followed by hepatitis within 0 to 11 weeks (seven patients-codes 15,23,26, 32, 33, 34 and 64). Abnormal liver function tests preceded detection of HB Ag in two patients (code nos. 15, 35). Hepatitis and the first detection of $\mathrm{HB} \mathrm{Ag}$ occurred simultaneously in two patients (code nos. 23, 64).

\section{MORTALITY AND MORBIDITY}

There was no mortality from hepatitis in the unit. No episodes of hepatic failure occurred in any patient. Patients who died during the study (see table II) had no clinical evidence of liver disease. No necropsies were performed because of the health risks involved.

PERSISTENCE OF HB AG

As of August 1973 it has been possible to follow 24 HB Ag-positive patients for a period exceeding six months (table IV). This shows a high frequency of $\mathrm{HB} \mathrm{Ag}$ carriers in the patients studied. Persistence of HB Ag cannot be definitely related to the presence or absence of initial hepatitis, overt or biochemical. Some patients who were $\mathrm{HB} \mathrm{Ag}$ positive and had subsequently been negative, developed positivity again (codes $04,06,16,23$ ). This may reflect the sensitivity of the techniques employed or alternatively reinfection with HB Ag. Patients 04 and 06 had been sent home $\mathrm{HB} \mathrm{Ag}$ negative but subsequently became positive at home. Of 24 patients followed up for more than six months, 15 are persistent carriers (nos. $03,08,12,15,16,23,31,32,33,34,44,50,52,53,54)$. No patients who remained positive for six months initially have become negative on further follow-up (table IV).

\section{ANTIBODIES}

Sixteen HB Ag-positive patients were examined for antinuclear, antimitochondrial, and antismooth muscle antibodies, before, during, and after hepatitis where possible. All antibody tests were negative in seven cases with jaundice (code nos. $4,10,15,17,26$ ), in six with anicteric hepatitis (code nos. $6,16,32,33$, $34,35,37$ ), and in three with no abnormality (code nos. $27,39,48)$.

\section{HB AG IN FAECES AND SPUTUM}

All tests for $\mathrm{HB} \mathrm{Ag}$ in faeces and sputum were negative, although the serum was positive for $\mathrm{HB} \mathrm{Ag}$ when faeces and sputum were collected.

\section{Discussion}

The occurrence of virus B hepatitis in long-term-stay institutions has been emphasized in recent years (Krugman and Giles, 1970; Prince, 1971), and is known in the general population in the area (Fitzgerald, Reynolds, Grimes, and McCarthy, 1973). It is clear that the outbreak of hepatitis is due to the

\begin{tabular}{|c|c|c|c|c|}
\hline Patient & $\begin{array}{l}\text { Follow Up } \\
(m t h)\end{array}$ & $\begin{array}{l}\text { Duration of } \\
\text { HBAg } \\
\text { Positivity } \\
\text { (mth) }\end{array}$ & Hepatitis & $\begin{array}{l}\text { Jaundice or } \\
\text { HB Ag in } \\
\text { Relatives }\end{array}$ \\
\hline $\begin{array}{l}03 \\
04 \\
08 \\
10 \\
14 \\
15 \\
16 \\
17 \\
20 \\
23 \\
26 \\
27 \\
30 \\
31 \\
32 \\
.33 \\
34 \\
44 \\
45 \\
50 \\
52 \\
53 \\
54 \\
\text { Also } \\
12\end{array}$ & $\begin{array}{r}24 \\
16 \\
22 \\
23 \\
7 \\
11 \\
20 \\
23 \\
22 \\
11 \\
22 \\
8 \\
6 \\
23 \\
11 \\
20 \\
18 \\
13 \\
17 \\
9 \\
11 \\
16 \\
17 \\
24\end{array}$ & $\begin{array}{r}24 \\
4 \\
22 \\
2 \\
2 \\
11 \\
19 \\
1 \\
5 \\
11 \\
2 \\
1 \\
5 \\
23 \\
11 \\
13 \\
18 \\
13 \\
1 \\
9 \\
11 \\
16 \\
17 \\
24\end{array}$ & $\begin{array}{l}+ \\
+ \\
+ \\
+ \\
- \\
+ \\
+ \\
+ \\
- \\
+ \\
+ \\
(+)^{1} \\
- \\
- \\
+ \\
+ \\
+ \\
+ \\
+ \\
+ \\
+ \\
\pm \\
- \\
-\end{array}$ & $\begin{array}{l}+ \\
+ \\
+ \\
+\end{array}$ \\
\hline
\end{tabular}

Table IV $\mathrm{HB}$ Ag persistence in positive patients followed up for a period exceeding six months from initial $\mathrm{HB} \mathrm{Ag}$ detection

${ }^{1}$ Enzyme pattern not typical of hepatitis. Liver biopsy showed amyloidosis and alpha-1-antitrypsin deficiency changes. 
presence of $\mathrm{HB} \mathrm{Ag}$ in the unit, because of the known association between the two, the high number of cases of hepatitis in the HB Ag-positive patients compared with the $\mathrm{HB}$ Ag-negative patients, the absence of $\mathrm{HB} \mathrm{Ag}$ and hepatitis in the female tuberculosis unit (where the patients receive the same chemotherapy), the temporal relationship between the patient's admission to the unit and his subsequent hepatitis, and the occurrence of $\mathrm{HB} \mathrm{Ag}$ and jaundice in the patient's relatives at home following his discharge from the unit.

The exact mode of transmission of $\mathrm{HB} \mathrm{Ag}$ cannot be defined. It is probable that several modes were operative in this outbreak. The infection of the doctor, the laboratory technician, and the two nurses can be assumed to be parenteral. Likewise, patients 29 and 44 may have originally been infected through previous blood transfusions. Most patients in the study had received streptomycin by intramuscular injection, and on assessment of this route as a possibility in transmission can be made from our data (table I). Thirty-one patients of 47 who received streptomycin injections became $\mathrm{HB} \mathrm{Ag}$ positive as against five of 16 patients who did not receive streptomycin. HB Ag-positive patients nos. 14, 15, 46,47 , and 50 did not have streptomycin at any time (nor any other intramuscular or intravenous injection). Although multiple-dose vials of streptomycin were used, only sterile disposable needles and syringes were employed. No instance of $\mathrm{HB} \mathrm{Ag-}$ positive hepatitis was found in the female tuberculosis unit of the same hospital, although similar injection techniques and streptomycin vials are employed. The parenteral route of transmission also fails to explain the occurrence of $\mathrm{HB} \mathrm{Ag}$ in the domestic staff and the relatives of patients. Close contact of the patients appears to be important in transmission and this is borne out by the spread of $\mathrm{HB} \mathrm{Ag}$ in the domestic staff and the relatives of patients. Close contact of the patients appears to be important in transmission and this is borne out by the spread of HB Ag to the patients' wives. The latter may, however, be due to sexual spread as suggested by Hersh et al (1971) and by Jeffries et al (1973). A high incidence of $\mathrm{HB} \mathrm{Ag}$ carrier state in patients with tuberculosis or chronic bronchitis (Petera, Vesely, Kulich, and Dura, 1972) suggests either an easy portal of entry of $\mathrm{HB} \mathrm{Ag}$ or an immunological abnormality leading to the carrier state, or both. The absence of $\mathrm{HB} \mathrm{Ag}$ in faeces could suggest a route of non-parenteral transmission other than the gastrointestinal tract. It is possible that airborne spread, with entry of the virus through a damaged respiratory tract, may have occurred but this cannot be shown. There was no case of massive haemorrhage or of blood spillage in the unit in the previous year to account for considerable aerial contamination, and the timing of such aerial contamination would not account for later infection of patients not yet admitted to the unit. Detailed efforts to relate spread to haircutting, shaving, laundry, lavatories, and water supply were not successful. The use of contaminated cutlery and kitchenware as a source of infection could not be ruled out. As urinary HB Ag was not examined, the possibility of this route contributing to infection cannot be commented upon. Sputum excretion of $\mathrm{HB} \mathrm{Ag}$ was not found. $\mathrm{HB} \mathrm{Ag}$ subdeterminants may be helpful as markers of the mode of transmission (Mosley, Edwards, Meihaus, and Redeker, 1972) and it is planned to study them in relation to this outbreak.

The origin of the outbreak is not clear. Staff in the unit have noted frequent cases of jaundice since 1969. From our data it can be seen that seven patients had previous admissions to the unit (code nos. 02, 07, 10, 31, 35, 44 and 61). Case 31 had HB Ag on admission to the unit and had previously been admitted in 1970, suggesting previous infection in the unit then. Case 02 had acute viral hepatitis in 1970, having been in the unit on several previous occasions. These pointers suggest that continuing $\mathrm{HB}$ Ag infection was present since 1969 or 1970 . The extent of this may not have been evident as many of the patients would still be in the hepatitis incubation period on discharge from the unit, later developing jaundice at home.

Search for a long-term carrier of the infection in the unit was unrewarding. No member of the staff had persistent antigenaemia and the only long-term patient (code 01) was not found to be $\mathrm{HB} \mathrm{Ag}$ positive. Incubation periods in the study of 14 to 34 weeks is longer than that of four to 15 weeks in the Willowbrook State School experiment (Krugman et al, 1967). However, the modes of transmission cannot be strictly compared.

The fact that we did not detect faecal $\mathrm{HB} \mathrm{Ag}$ is in contrast to the findings of Grob and Jemelka (1971) who found faecal HB Ag in each of 11 patients with sporadic acute hepatitis.

Autoantibodies were found in none of the patients examined, in contrast to the findings of Walker et al (1970) and Ajdukiewicz et al (1972).

The high incidence of carriers of $\mathrm{HB} \mathrm{Ag}$ for periods of more than six months is notable and confirms the findings of Petera et al (1972) in tuberculous patients. It is of interest that all 15 patients with $\mathrm{HB} \mathbf{~ A g}$ persisting for periods exceeding six months have remained carriers for the duration of follow up. The very high incidence of $\mathrm{HB} \mathrm{Ag}$ positivity in the unit as opposed to that in the general population, combined with the high carrier state, suggests that the unit may be the main reservoir for $\mathrm{HB} \mathrm{Ag}$ infection in the west of Ireland. The fact that there has been no 
notable increase in HB Ag-positive hepatitis in this area recently and the small number of contacts infected is suggestive of low infectivity outside hospital. It is not yet possible to say what the incidence of chronic hepatitis will be among the patients studied.

The unit was closed to all new admissions in December 1971 and HB Ag-positive cases were kept in isolation from others. Nursing and kitchen facilities were divided between the two groups. By July 1973 the unit was empty. Before this HB Agnegative cases of tuberculosis were being admitted to a new unit in the hospital grounds. No recent inpatient jaundice has occurred and only one patient, who was previously in the original unit, has been found positive in recent months. Since the study was completed a report from an oncology unit confirms the danger of spread to personnel in contact with $\mathrm{HB}$ Ag-positive patients (Wands, Walker, Davis, Waterbury, Owens, and Carpenter, 1974). The demonstration of $\mathrm{HB} \mathrm{Ag}$ in the saliva of $76 \%$ patients with acute hepatitis and $86 \%$ of $\mathrm{HB} \mathrm{Ag}$ carriers (Villarejos, Visoná, Gutiérrez, and Rodriguez, 1974) suggests that spread of infection is particularly likely to be brought about by droplet spread during coughing.

We wish to acknowledge the technical assistance of Mr J. Finn, who carried out the immunofluorescent antibody tests in Professor J. D. Kennedy's Department.

\section{References}

Ajdukiewicz, A. B., Fox, R. A., Dudley, F. J., Doniach, D., and Sherlock, S. (1972). Immunological studies in an epidemic of infective, short incubation hepatitis. Lancet, 1, 803-806.

Almeida, J. D., Kulatilake, A. E., Mackay, D. H., Shackman, R., Chisholm, G. D., MacGregor, A. B., O'Donoghue, E. P. N., and Waterson, A. P. (1971). Possible airborne spread of serum-hepatitis virus within a haemodialysis unit. Lancet, 2, 849-850.

Berg, K., Vellar, O. D., and Nesvold, H. P. (1971). Search for AustraliaSH antigen and antibody after a Norwegian hepatitis outbreak. (Letter) Lancet, 1, 1015.
Blumberg, B. S., Melartin, L., Guinto, R. A., and Werner, B. (1966). Family studies of a human serum Iso-antigen system (Australia antigen). Amer.J. hum. Genet., 81, 594-608.

Cossart, Y. E., and Vahrman, J. (1970). Studies of Australia-SH antigen in sporadic viral hepatitis in London. Brit. med. J., 1, 403-405.

Del Prete, S., Constantino, D., Doglia, M., Graziina, A., Ajdukiewicz, A., Dudley, F. J., Fox, R. A., and Sherlock, S. (1970). Detection of a new serum-antigen in three epidemics of short-incubation hepatitis. Lancet, 2, 579-581.

Fitzgerald, G. R., Reynolds, M., Grimes, H., and McCarthy, C. F. (1973). Hepatitis associated antigen in the West of Ireland. Irish J. med. Sci., 142, 249-254.

Grob, P. J., and Jemelka, H. (1971). Faecal SH (Australia) antigen in acute hepatitis. Lancet, 1, 206-208.

Heathcoate, J., Cameron, C. H., and Dane, D. S. (1974). Hepatitis-B antigen in saliva and semen. Lancet, 1, 71-73.

Hersh, T., Melnick, J. L., Goyal, R. K., and Hollinger, F. B. (1971). Nonparenteral, transmission of viral hepatitis type B (Australia antigen-associated serum hepatitis). New Engl. J. Med., 285, 1363-1364.

Jeffries, D. J., James, W. H., Jefferiss, F. J. G., MacLeod, K. G., and Willcox, R. R. (1973). Australia (hepatitis-associated) antigen in patients attending a veneral disease clinic. Brit. med. J., 2, 455-456.

Krugman, S., and Giles, J. P. (1970). Viral hepatitis; new light on an old disease. J. Amer. med. Ass., 212, 1019-1029.

Krugman, S., Giles, J. P., and Hammond, J. (1967). Infectious hepatitis: evidence for two distinctive, clinical, epidemiological, and immunological types of infection. J. Amer. med. Ass., 200, 365-373.

Mirick, G. S., and Shank, R. E. (1959). An epidemic of serum hepatitis studied under controlled conditions. Trans. Amer. clin. climat. Ass., 71, 176-190.

Mosley, J. W., Edwards, V. M., Meihaus, J. E., and Reeker, A. G. (1972). Subdeterminants $d$ and $y$ of hepatitis $B$ antigen as epidemiological markers. Amer.J. Epidem., 95, 529-535.

Petera, V., Vesely, V., Kulich, V., and Dura, J. (1972). The clinical and morphological correlations in the $\mathrm{Au} / \mathrm{SH}$ antigen carriers. Digestion, 5, 227-228.

Prince, A. M. (1971). Role of serum hepatitis virus in chronic liver disease. Gastroenterology, 60,913-921.

Prince, A. M., Hargrove, R. L., Szmuness, W., Cherubin, C. E., Fontana, V. J., and Jeffries, G. H. (1970). Immunologic distinction between infectious and serum hepatitis. New Engl. J. Med., 282, 987-991.

Walker, J. G., Doniach, D., Willette, M., Cameron, C. H., and Dane, D. S. (1970). Virus antigen, immunoglobulins and autoantibodies in acute hepatitis. Gut, 11, 369.

Villarejos, M., Visoná, K. A., Gutiérrez, A. D., and Rodriguez, A. A. (1974). Role of saliva, urine and feces in the transmission of type B hepatitis. New Engl.J. Med., 291, 1375-1378.

Wands, J. R., Walker, J. A., Davis, T. T., Waterbury, L. A., Owens, A. H., and Carpenter, C. C. J. (1974). Hepatitis B in an oncology unit. New Engl. J. Med., 291, 1371-1375.

Wright, R., Perkins, J. R., Bower, B. D., and Jerrome, D. W. (1970). Cirrhosis associated with the Australia antigen in an infant who acquired hepatitis from her mother. Brit. med. J., 4, 719-721. 